\title{
RRM2 wt Allele
}

National Cancer Institute

\section{Source}

National Cancer Institute. RRM2 wt Allele. NCI Thesaurus. Code C50930.

Human RRM2 wild-type allele is located within 2p25-p24 and is approximately $8 \mathrm{~kb}$ in length. This allele, which encodes ribonucleoside-diphosphate reductase M2 subunit protein, plays a role in the reduction of ribonucleotides to deoxyribonucleotide precursors for DNA synthesis in dividing cells. 